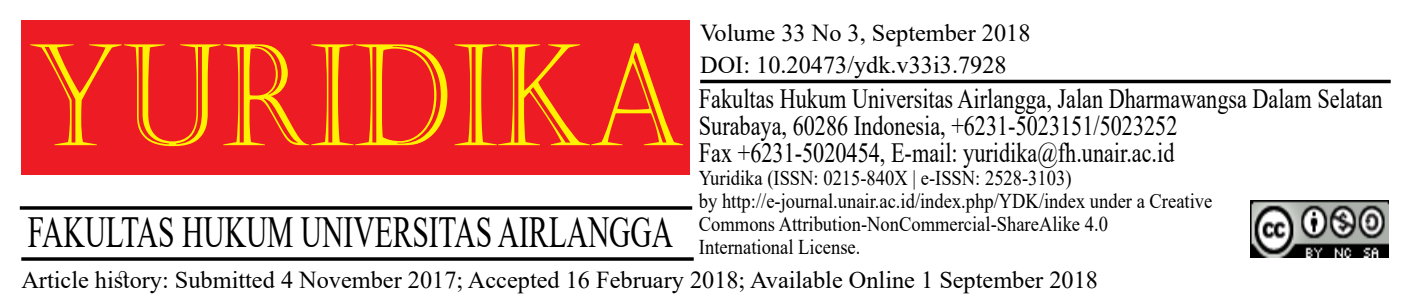

\title{
Alternative Solution on the Execution of Court's Verdict Within Employment Termination Dispute
}

\author{
Budi Santoso \\ budi.santoso@ub.ac.id \\ Brawijaya University
}

\begin{abstract}
This paper aims to analyze the juridical barriers of execution of verdict in case of dismissal dispute as well as offering a solution to the execution of such verdict to be carried out so that workers obtain their rights. Through the statute and case approaches, it is concluded that the juridical barriers are: 1) in a reminder implementation, the existing regulation does not authorize the bailiff to force the defendant to attend the reminder call if the defendant refuses to attend the call voluntarily; and 2) in the execution seizure, the goods to be confiscated shall belong to the defendant, whereas the plaintiff can not prove it because all the evidence is in the hands of the employer. While alternative solutions in order the verdict may be executed well are: 1) involving authorized third parties who may assist the worker as a plaintiff to prove the ownership of the items for which the request is for confiscation; and 2) implementing the body's forced effort to an employer with a bad faith in accordance with Supreme Court Regulation No. 1 Year 2000, but by reducing the minimum limit of debt that is not as much as one billion rupiah due to cases of dismssal dispute are less possibility of paying for the workers' rights who reached that amount.
\end{abstract}

Keywords: The Execution of Labour Court's; Verdict; Employment Termination. 


\section{Introduction}

Employee-Employer relationship is one of the fundamental aspects of labor law. ${ }^{1}$ Such relations are at the core of relationships for employers and workers. The difference is for employer, work relationships are placed in the interests so that their business can run well and profitably. In addition, the awareness of entrepreneurs is increasing to fulfill the laws and regulations related to the safety and maintenance of health workers. ${ }^{2}$ For this reason, the employer wants to have the freedom to determine whether to continue the employment relationship or terminate the workers. While for workers, the maintenance of a working relationship means the guarantee of a source of income for their survival. Therefore, workers will continually strive to maintain a working relationship. ${ }^{3}$

Legally, employers and workers have the same position. Both parties have the freedom to make and determine the contents of the work agreement. Workers and employers on the principle are equally free to start and terminate the employment relationship in accordance with the principle of freedom of contract contained in the contract law. However, in practice, the employers who always take the initiative in terminating the employment relationship. Thus, the position of workers and employers is legally equal, but when viewed from the reality, the position is not equal. Workers are generally in a weak position compared to employers.

Workers are groups that depend on their lives and their families for the company where they work. Most of the workers who were subject to layoffs could no longer work in other companies due to several things, such as age problems and limited employment offer. This means that the rights of the laid-off workers, especially severance pay, are the main capital to continue living for the lives of workers and their families. To protect from unbalanced conditions, the government

\footnotetext{
${ }^{1}$ Budi Santoso, Hukum Ketenagakerjaan: Perjanjian Kerja Bersama (Universitas Brawijaya Press 2012).[2].

${ }^{2}$ Lanny Ramli, 'Hambatan-Hambatan Dalam Penegakan Hukum Jaminan Sosial Tenaga Kerja' (1997) XII Yuridika.[10].

${ }^{3}$ Mohd. Syaufii Syamsuddin, Hukum Acara Penyelesaian Perselisihan Hubungan Industria (Sarana Bhakti Persada 2010).[89].
} 
has taken steps to protect workers from layoffs through regulation of prevention efforts so as not to be laid off. If layoffs remain unavoidable, then it must be run fairly and properly, both procedure and substance. ${ }^{4}$

The most extensive and complete protection for workers provided by labor legislation is protection for workers from layoffs. This is understandable because for workers, layoffs are troublesome. Therefore, workers must be protected against layoffs. The protection includes prevention efforts, prohibitions on layoffs, reasons for termination of employment, and rights received by workers as compensation for termination of employment in the form of severance pay, tenure, compensation, and termination fees. ${ }^{5}$

Although labor laws and regulations have provided a lot of protection for laidoff workers, in practice, these protections cannot work effectively. Often workers in termination dispute have attempted to go through the bipartite negotiations, mediation, filing a lawsuit to the Industrial Relations Court, appealing to the Supreme Court, until the decision is legally binding, but workers still denied to get their rights. This is because these decisions cannot be implemented or executed.

Based on the above background, this article aims to analyze the existence of juridical barriers in the execution of court's decisions on the Industrial Relations Court regarding worker termination dispute and offer solutions that can be carried out so that the execution of these decisions can run well so that dismissed workers can obtain his rights. To answer the above, this legal research uses a statute approach and a case approach. This is consistent with the prescriptive character of law, which is to obtain results that contain values. The statute approach is used with the consideration that the study will examine the laws and regulations related to the settlement of industrial relations disputes, especially for resolving disputes on worker termination. A case approach is used to see the basis of the judge's ratio decidendi in the Industrial Relations Court in deciding the dispute.

\footnotetext{
${ }^{4}$ Budi Santoso, 'Fairness in Dismissal for Business Reasons in Indonesia' (2017) 25 Journal of Advanced Research in Law and Economics.[784].

${ }_{5}$ Mohd. Syaufii Syamsuddin (n 3).Op.Cit.[95].
} 


\section{Juridical Barriers on the Execution of Court's Verdict in Employment Termination Dispute}

Article 151 paragraph 1 of Law Number 13 of 2003 concerning Manpower (hereinafter referred to as the Manpower Act) regulates that employers, workers/ abors, workers/labor unions, and the government must make every effort to prevent layoffs. This confirms that the step of layoffs must be the last step taken by employers. If all means of avoiding it have been carried out and if layoffs cannot be avoided, then the step must be deliberated and resolved as well as possible. Although workplaces dispute should ideally be resolved through collaborative and less confrontational means, ${ }^{6}$ but it is not uncommon for the settlement steps to be successful. For such conditions, the parties brought the settlement through the Industrial Relations Court. This is like some examples of industrial relations disputes below.

On June 17, 2009, in case No. 61/G/2009/PHI.Smg, Suhartanto (Plaintiff) sued the TITD Foundation of Sam Pho Khong Great Temple (Defendant) at the Industrial Relations Court at the Semarang District Court. The Plaintiff is a worker at the Defendant who has a work period of 22 years and 11 months with the last salary of Rp. 250,000. This wage is lower than the Semarang City Minimum Wage in 2008 of Rp. 715,700.7 The Plaintiff's reason was because the Defendant had terminated the Plaintiff without reason so the Plaintiff asked the Defendant to pay severance pay twice the provisions of Article 156 paragraph 2, the reward period of employment amounting to one time the provisions of Article 156 paragraph 3, and compensation money rights equal to one time the provisions of Article 156 paragraph 4 of the Manpower Act by basing on the Semarang City minimum wage in 2008 totaling Rp. $21,399,430$.

In case No. 36/G/2010/PHI.Smg, Plaintiff, Muji Astutik (Plaintiff) sued PT. Holi Karya Sakti (Defendant) on March 23, 2010 at the Industrial Relations Court

\footnotetext{
${ }^{6}$ Ashgar Ali Ali Muhamed, 'Resolution of Industrial Disputes in New Zealand' (2012) 6 International Journal of Humanities and Social Science.[208].

7 East Java Governor Decree Number 561.4/51/2007 Concerning Minimum Wages in 35 Districts/Cities in Central Java Province in 2008.
} 
at the Semarang District Court. The Plaintiff is a worker at the Defendant who has a work period of 14 years with the last salary plus a fixed allowance of Rp. 725,700. The Plaintiff's reason was because the Defendant had terminated the Plaintiff without reason so the Plaintiff asked the Defendant to pay severance pay twice the provisions of Article 156 paragraph 2, the reward period of employment amounting to one time the provisions of Article 156 paragraph 3, and compensation money one time right provisions of Article 156 paragraph 4 of the Manpower Act.

In case No. 44/G/2011/PHI.Smg, Wahidah (Plaintiff) sued PT. Holy Karya Sakti on October 19, 2007 at the Industrial Relations Court at the Semarang District Court. The Plaintiff is a worker at the Defendant who has worked for 8 years and 7 months with the last salary of Rp. 715,700. The reason was that the Defendant had dismissed the Plaintiff without reason. Therefore, the Plaintiff requested the Defendant to pay severance pay twice the provisions of Article 156 paragraph 2, the reward period of employment amounting to one time the provisions of Article 156 paragraph 3, and the one-time stipend of Article 156 paragraph 4 Manpower Act.

In case No. 40/G/2013/PHI.Smg, Sainah (Plaintiff) sued PT. Kebon Agung PG. Trangkil (Defendant) in the Industrial Relations Court at the Semarang District Court. The Plaintiff is the heir of the late Joyo Sudadi who is a worker at the Defendant who has had a work period of 23 years with the last salary of Rp. $1,018,500$. The reason for the Plaintiff was that the Defendant did not give the rights of the late Joyo Sudadi who died from a work accident so that the Plaintiff asked the Defendant to pay the deceased compensation consisting of death benefits, periodic compensation, and funeral fees totaling Rp. 54,000,000. In addition to asking for compensation money, also severance pay of twice the provisions of Article 156 paragraph 2, the reward period of employment equal to one time the provisions of Article 156 paragraph 3, and the compensation for rights of one time the provisions of Article 156 paragraph 4 Law Manpower Act.

For these claims, after going through the examination and verification process at the trial, the judge then makes a decision which can refuse or grant it. Those who are not satisfied with the decision have the right to file legal remedies. If the decision 
has obtained permanent legal force, the decision can be carried out. The defeated party can voluntarily carry out the decision. Therefore, the case will be completed without the need for court assistance in carrying out the decision. However, it often happens that the defeated party does not want to carry out the judge's decision voluntarily so that the court's help is needed to enforce the decision by force. The party won in the decision can request the execution of the decision (execution) to the court that will execute it by force (execution). ${ }^{8}$

The implementation of the judge's decision or execution is essentially nothing but the realization of the obligation of the losing party to fulfill the achievements stated in the decision. There are several types of execution, namely: ${ }^{9}$

1. Execution of decisions that punish people for committing an act. This is regulated in Article $225 \mathrm{HIR}$ and Article $259 \mathrm{RBg}$. One cannot be forced to fulfill an achievement in the form of an act. However, the party won can ask the judge so that the interest he will get is judged by money. An example of this execution in industrial relations disputes is the execution of decisions that punish employers to re-employ workers to their original place;

2. Real execution is execution which is the charged of an achievement to the debtor by a judge's decision directly. So the real execution is the implementation of decisions that lead to the same results as if carried out voluntarily by the parties concerned; and

3. Execution that punishes the losing party to pay some money. The required achievement is to pay a sum of money. This execution is regulated in Article 196 HIR and Article $208 \mathrm{RBg}$. An example of this execution in industrial relations disputes is the execution of decisions that punish employers for paying severance pay, tenure awards, and reimbursement of rights to laid-off workers.

As stated above that if a judge's decision has permanent legal force, then the losing party shall be willing to carry out the contents of the decision voluntarily.

${ }^{8}$ Retnowulan Sutantio and Iskandar Oeripkartawinata, Hukum Acara Perdata Dalam Teori Dan Praktek (Mandar Maju 1997).[129].

9 Sudikno Mertokusumo, Hukum Acara Perdata Indonesia (Universitas Atma Jaya 2010).[338]. 
However, if it turns out the losing party is not willing, then the first step taken by the winning party is to submit an application to the Chairperson of the local State Justice so that the losing party is given a warning (Aanmaning). The aanmaning application is made in writing which contains the identities of the parties in the case, In practice, this application is accompanied by a copy of the decision that has a permanent legal force) as well as what reasons so that the aanmaning application is submitted and requested for execution. ${ }^{10}$

In its implementation, these guidelines encounter juridical constraints, namely if the defendant intentionally or unintentionally does not attend the call, the current regulation does not authorize the bailiff to force the defendant to attend an aanmaning call if the defendant does not want to attend it voluntary. So often the defendant has been given the summons many times but the defendant still does not want to attend. This is as in the following cases:

1. In case No. 44/G/2011/PHI.Smg reinforced by the Supreme Court Cassation Decision No.241K/Pdt.Sus/2012 thus it has permanent legal force, the Petitioner (formerly Plaintiff), namely Wahidah, submitted an application for execution to the Chairperson of the IRC at Semarang District Court on February 25, 2013. Respondent (former Defendant), namely PT. Holy Karya Sakti, was given a Call Letter by the Substitute of the Semarang District Court to attend the $1^{\text {st }}$ Call (Aanmaning) on September 16, 2013. But on the first call, the Respondent did not come. On October 4, 2013, the Respondent was summoned again by the Substitute Officer to attend the second Aanmaning, but the Respondent still did not come. On November 8, 2013, the Respondent was called again to attend the third Aanmaning, but the Respondent still did not come;

2. In case No. 85/G/2009/PHI. Reinforced by the Supreme Court decision No. 409K/Rev.Sus/2010, the Petitioner (formerly the Plaintiff), namely Muthoharoh, submitted an application for execution to the Chairperson of the IRC at the Semarang District Court on March 7, 2011. The Respondent

\footnotetext{
${ }^{10}$ Mohammad Saleh and Lilik Mulyadi, Seraut Wajah Pengadilan Hubungan Industrial Indonesia (PT Citra Aditya Bakti 2012).[276].
} 
(former Defendant), namely PT. Holy Karya Sakti, has been given a Call Letter by the Substitute of the Semarang District Court to attend $1^{\text {st }}$ Aanmaning on September 12, 2013. But on the first call up to the third the Respondent did not come.

3. In case No. 24/G/2010/PHI. Reinforced by the Supreme Court decision No. 845/Rev.Sus/2010, the Petitioner (formerly the Plaintiff), namely M. Husni, submitted an application for execution to the Chairperson of the IRC at Semarang District Court on June 6, 2011. The Respondent (former Defendant), namely PT. Maharupa Gatra, on the 8th of October 2010 the first till third Aanmaning Letter was given, but the Respondent did not come.

After aanmaning and the respondent promises to fulfill the judge's decision at a certain time, but the respondent still does not fulfill it, the applicant submits an application for seizure of execution, especially if the decision is in the form of a payment of money. The request for seizure of execution is not necessary if it turns out that during the first level of trial process, the judge has placed a guarantee confiscation and the decision is declared valid and valuable. Confiscate guarantees that are declared valid and valuable can be executed for compensation. The seizure can be placed on all assets of the defendant both movable and immovable property. If the amount of movable property is calculated, it is not enough to pay the amount of money that must be fulfilled by the defendant, then the deficiency can only be taken from immovable property.

In case No. 44/G/2011/PHI. The Petitioner (formerly the Plaintiff) submitted an application for execution to the Chairperson of the PHI at Semarang District Court on February 25, 2013. The applicant for the execution also filed a confiscation execution of the assets of the Respondent (first Defendant) in the form of three fourwheeled vehicles. Also in case No. 36/G/2010/ PHI. The Petitioner (formerly the Plaintiff) submitted an application for execution to the Chairperson of the IRC at Semarang District Court on January 7, 2012. The applicant for the execution also filed a confiscation of the inventory assets of the Respondent for execution (former Defendant) in the form of three four-wheeled vehicles. 
However, in its implementation there are juridical difficulties, namely the items to be confiscated must be the property of the defendant so that evidence is needed that the items to be confiscated are actually the property of the defendant. Even though the items submitted for confiscation are in the place of the defendant, it is not necessarily the property of the defendant. It may be that the goods requested to be confiscated belong to another person borrowed or rented by the defendant or the goods belong to the defendant but have been subject to material security rights such as fiduciary. This causes the items requested for confiscation to be required proof that the item really belongs to the defendant.

In decision No. 44/G/2011/PHI.Smg and decision No. 36/G/2010/PHI.Smg, although the Plaintiff can show the items for which the execution will be requested, the Plaintiff cannot show evidence that the items requested for seizure belong to the Defendant. The absence of a seizure execution of the property of the defendant caused the auction unable to be carried out. Because there are no items that can be auctioned, there is no payment of money to the plaintiff as ordered by the panel of judges to the defendant in the decisions above. It can be said that workers as plaintiffs only win on paper.

\section{Alternative Solution for the Verdict on Employment Termination to be Executed}

According to Harifin A. Tumpa, there are two kinds of ways that can be taken to implement a judge's decision, namely: ${ }^{11}$

1. Direct effort (directe middelen), namely the plaintiff obtains achievements from the defendant in accordance with what is determined or ordered by the judge in the decision. This effort can be divided into two ways, namely:

a. real execution (reele executie), that is, the defendant is directly forced (if necessary with the power of the authorities) to fulfill what is ordered by the judge. This method is to carry out an achievement in the form of handing over

\footnotetext{
${ }^{11}$ Harifin A. Tumpa, Memahami Eksistensi Uang Paksa (Dwangsom) Dan Implementasi Di Indonesia (Kencana Prenada Media Group 2010).[1].
} 
an item other than money, doing and not doing something; and

b. the penalty for fulfilling an achievement in the form of payment of money is carried out by first confiscating the movable property of the defendant, then the items are sold (auctioned) and the proceeds are used for payment of a sum that must be paid by the defendant (verhaal executie).

2. Indirect efforts (indirecte middelen), namely the fulfillment of achievement is achieved through psychological pressure on the defendant so that the person voluntarily fulfills the achievement. This effort is known in two ways:

a. the application of forced money (dwangsom), namely the judge prescribes an additional sentence to the convict to pay a sum of money to the plaintiff in the event that the convict does not fulfill the principal sentence. This additional punishment was intended to pressure the convicted to fulfill the principal sentence voluntarily; and

b. the application of hostage (gijzeling), namely the judge stipulates that if the convicted person does not want to fulfill the stipulated performance then the convicted will be held hostage.

Basically, the execution of a direct effort against a decision that convicts a defendant to commit a certain act is difficult to be implemented. This is because the fulfillment of the decision can only be carried out by the convicted person. In industrial relations disputes, the decision of a judge who convicts the defendant (employer) to re-employ the plaintiff (worker) is a decision to carry out a particular act. The decision will be difficult to implement if the employer does not want to voluntarily comply with the decision.

An example of the above situation, in the Semarang PHIdecision No.33/G/2009/ PHI.Smg, the panel of judges ruled that layoffs by employer were contrary to the law and subsequently sentenced employer to call and re-employ workers. At the appeal level, through decision No.701 K/Pdt.Sus/2009, the Supreme Court justifies the first PHI decision by stating that the panel of judges did not misapply the law. However, the decision was not implemented by the employer. Another example is in the Semarang PHI decision No. 116/G/2008/PHI.Smg, the panel of judges 
ruled that layoffs against workers were contrary to the law and punished employer to re-employ workers to their original place. However, for this decision also, the employer does not carry it out.

In anticipation of the above non-compliance, the law actually provides a way for plaintiffs to file additional claims to the defendant in the form of a sum of money so that the judge's decision is determined so that the convict must pay a sum of money (forced money) if the principal sentence is not met. Strictly speaking, this forced money (dwangsom) is of additional punishment (subsidair) whose existence depends on the principal punishment (primair), meaning that $d$ wangsom can be carried out and has the power of execution if the convicted person is deemed unwilling to voluntarily fulfill the principal punishment until the warning period or aanmaning is exceeded.

Dwangsom or forced money is regulated in Article 606a and 606b RV. Article 606a RV states “As long as a judge's decision contains a penalty for something other than paying a sum of money it can be determined that as long as or every time the convict does not fulfill the sentence, he must be given a sum of money and the money is called forced money (dwangsom), while Article 606b states "If the judge's decision is not fulfilled then the opposing party. It is authorized to carry out the decision on a set amount of forced money without first obtaining a new right under the law". Referring to these provisions it can be understood that the decision of a judge who can impose a $d$ wangsom sentence is a judge's decision in the civil field that is comdemnatoir.

It can be said that the dwangsom serves as a way to exert psychological pressure so that the defendant will carry out the main sentence. Because if not, the unwillingness of the defendant to postpone the execution of the main sentence will only further burden the defendant, namely that in addition to still having to fulfill the main sentence, the defendant must also pay forced money. The execution of the punishment for forced money is carried out by verifying the executie based on the provisions of Article 195-208 HIR and Article 206-240 RBg. Based on these provisions and habits in judicial practice, then the outline of the execution stages includes a warning (aanmaning), confiscation, auction. ${ }^{12}$

${ }^{12}$ Lilik Mulyadi, Tuntutan Provisionil Dan Uang Paksa (Dwangsom) Dalam Hukum Acara Perdata (Alumni 2012).[274-279]. 
Not only for the judge's decision to punish employers for reinstating workers in their original jobs, difficulties in carrying out executions were also experienced for judges 'decisions that punish employers for paying workers' rights due to layoffs. In the judge's decision on disputes on termination of employment that sentenced employers to pay a sum of money (severance pay, term of service, and compensation for the rights that should have been received by workers), it was not uncommon for employers to not fulfilling this obligation. Instead of fulfilling these obligations, the entrepreneur actually let it drag on. This is clearly detrimental to the interests of workers.

Judging from the nature of the decision that punishes employers to fulfill an achievement in the form of payment of a sum of money, it can be possible to apply forceful measures (gijzeling). Gijzeling is regulated in Article 209-223 HIR and Article 242-257 RBg. In Article 209, the HIR states that if there is no or not enough goods to ensure the execution of a decision, then the head of the district court at the request of the victor by oral or by letter, gives an order with a letter to the ruling person to carry out a warrant, so that the debtor it is flagged. Whereas the length of hostage must be mentioned in the warrant. In his explanation it was stated that aside from the methods of execution by confiscating and selling auctions of goods belonging to the losing party, if the convicted person did not want to comply with the judge's decision, there was another way to hold it (gijzeling), which is to hold the losing party in the penitentiary's house with the intention of forcing him to fulfill the judge's decision.

Gijzeling may only be used if the items to fulfill a decision are missing or insufficient. This is an important execution tool, because it involves human freedom. The head of the district court issues a warrant to take hostage because at the request, either verbally or in writing, from the winning party. The order states how long the losing party will be detained. The order was executed by the ruling party, the bailiff. The cost of detention, especially the cost of maintaining the person being held hostage, is temporarily borne by the party making the request to take hostage. These costs in the future, if the detained person meets the hostage, will be told to bear the hostage. 
The regulation on gijzeling, namely Article 209-223 HIR and Article 247-257 $\mathrm{RBg}$, by the Supreme Court is no longer effective effectively through the Supreme Court Circular (SEMA) No. 2 of 1964. The SEMA instructed that all courts in the general court environment no longer use the gijzeling or hostage articles for reasons because the act of taking hostages against a debtor was deemed contrary to humanity. In 1975, the Supreme Court strengthened the application of SEMA No. 2 of 1964 with the Supreme Court Circular Letter (SEMA) No. 4 of 1975 which states that gijzeling is an act of "depriving a person of freedom of movement" in the context of executing a civil case decision that has definite strength, which case decision has begun with the seizure of property of the losing party, but it has been found out that the person it does not have any property or the property is not enough to pay off its debts.

Even so, the gijzeling based on the HIR and RBg above is not directed at the dissident party, namely the defendant who is actually able to pay, but the person concerned does not have good intentions by not paying according to what was decided by the panel of judges. Gijzeling is based on HIR and RBg if the defendant's property to fulfill the contents of the decision is absent or insufficient. This is according to the Supreme Court as an inhumane act, so it is prohibited from being used again.

On June 30, 2000, the Supreme Court issued the Supreme Court Regulation (PERMA) No. 1 of 2000 concerning Forced Institutions. This PERMA revoked SEMA No. 2 of 1964 and SEMA No. 4 of 1975 because the two SEMAs were deemed no longer suitable with the legal conditions and needs in the context of law enforcement of justice and economic development of the Indonesian people. In this PERMA also stated that the translation of the term "gijzeling" with the word "hostage" or "hostage-taking" as contained in SEMA No. 2 of 1964 and SEMA No. 4 of 1975 was deemed inappropriate because it did not include an understanding of debtors who were capable but did not want to fulfill their obligations in paying debts, so that the translation needed to be refined to become "Forced Body", as contained in the universally valid "Imprisonment for Civil Debts" definition. 


\section{Conclusion}

The juridical barriers on the execution of court's verdict in employment termination dispute, among others are in implementing aanmaning, the current regulation does not give authority to the bailiff to force the defendant to attend the summons if the defendant does not want to attend the call voluntarily, so the defendant has often been given an aanmaning call many times but the defendant still does not want to attend. In the execution of seizure, the items to be confiscated must be the property of the defendant. This being said, there should be evidence that the item to be confiscated is actually the property of the defendant, while the worker as the plaintiff cannot prove it because all evidence is in the hands of the businessman as the defendant.

Alternative solution for the Verdict on Employment Termination to be Executed by involving authorized third parties who can assist the workers as plaintiffs to prove ownership of the items requested for confiscation. Applying the gijzeling to the defendant whose intentions are not in accordance with PERMA No. 1 of 2000, but by reducing the minimum debt limit that no longer amounts to at least one billion rupiah. This is because for cases of disputes on termination of employment, it is very unlikely that the payment of workers' rights will reach that value.

\section{Bibliography}

Budi Santoso, 'Fairness in Dismissal for Business Reasons in Indonesia' (2017) 25 Journal of Advanced Research in Law and Economics.

— Hukum Ketenagakerjaan: Perjanjian Kerja Bersama (Universitas Brawijaya Press 2012).

Decision of Industrial Relations Court at Semarang District Court Number 116/G/2008/PHI.Smg.

Decision of Industrial Relations Court at Semarang District Court Number 61/G/2009/PHI.Smg.

Decision of Industrial Relations Court at Semarang District Court Number 24/G/2010/PHI.Smg. 
Decision of Industrial Relations Court at Semarang District Court Number 36/G/2010/PHI.Smg.

Decision of Industrial Relations Court at Semarang District Court Number 44/G/2011/PHI.Smg.

Decision of Industrial Relations Court at Semarang District Court Number 40/G/2013/PHI.Smg.

Harifin A. Tumpa, Memahami Eksistensi Uang Paksa (Dwangsom) Dan Implementasi Di Indonesia (Kencana Prenada Media Group 2010).

Herzien Inlandsch Reglement (HIR).

Lanny Ramli, 'Hambatan-Hambatan Dalam Penegakan Hukum Jaminan Sosial Tenaga Kerja' (1997) XII Yuridika.

Law Number 13 Year 2003 Concerning Manpower.

Lilik Mulyadi, Tuntutan Provisionil Dan Uang Palsa (Dwangsom) Dalam Hukum Acara Perdata (Alumni 2012).

Mohammad Saleh and Lilik Mulyadi, Seraut Wajah Pengadilan Hubungan Industrial Indonesia (PT Citra Aditya Bakti 2012).

Mohd. Syaufii Syamsuddin, Hukum Acara Penyelesaian Perselisihan Hubungan Industria (Sarana Bhakti Persada 2010).

Rechtreglement voor de Buitengewesten (RBg).

Retnowulan Sutantio and Iskandar Oeripkartawinata, Hukum Acara Perdata Dalam Teori Dan Praktek (Mandar Maju 1997).

Sudikno Mertokusumo, Hukum Acara Perdata Indonesia (Universitas Atma Jaya 2010).

Supreme Court Circular Letter Number 2 Year 1964.

Supreme Court Circular Letter Number 4 Year 1975.

Supreme Court Decision Republic of Indonesia Number. 701K/Rev. Sus/2009.

Supreme Court Decision Republic of Indonesia Number. 409K/Rev. Sus/2010.

Supreme Court Decision Republic of Indonesia Number. 241K/Rev. Sus/2012. 
Supreme Court Regulation Number 1 Year 2000 Concerning Forced Institutions.

Wetboek op de Burgerlijke Rechtvordering (RV).

HOW TO CITE: Budi Santoso, 'Alternative Solution on The Execution of Court's Verdict Within Employment Termination Dispute' (2018) 33 Yuridika. 